\title{
Flipper tagging with archival data recorders for short-term assessment of diving in nesting female turtles
}

\author{
Tomoharu Eguchi ${ }^{1, *}$, Jeffrey A. Seminoff ${ }^{1}$, Steven A. Garner ${ }^{2}$, \\ Jeanne Alexander-Garner ${ }^{2}$, Peter H. Dutton ${ }^{1}$
}

${ }^{1}$ NOAA - National Marine Fisheries Service, Southwest Fisheries Science Center, 8604 La Jolla Shores Drive, La Jolla, California 92037, USA

${ }^{2}$ West Indies Marine Animal Research and Conservation Service, 202 Prosperity, Frederiksted, St. Croix, US Virgin Islands 00840, USA

\begin{abstract}
Archival data recorders (ADRs) were deployed on nesting female leatherback turtles Dermochelys coriacea to record short-term diving behavior. Plastic cattle ear tags were used as a platform to which an archival depth recorder was attached. The tags were applied to the hind flippers of 10 turtles, ranging from 141.9 to $160.6 \mathrm{~cm}$ in curved carapace length at Sandy Point National Wildlife Refuge, St. Croix, US Virgin Islands. We later retrieved 7 of the original 10 tags at the beach; durations of deployment ranged from 22 to $90 \mathrm{~h}$. The recorded number of dives per deployment ranged from 118 to 310. Maximum dive depths ranged from 175.6 to $479.7 \mathrm{~m}$ (mean 275.4, SE 41.7, $\mathrm{n}=7$ ), and maximum dive durations ranged from 16.3 to 27.8 min (mean 21.3, $\mathrm{SE}=1.5, \mathrm{n}=7$ ). Dive data indicated that post-nesting females dove deeper, less frequently, and longer than pre-nesting females - depth: mean $_{\text {post }} 78.6 \mathrm{~m}, 95 \%$ CI $(56.0,101.2)$ versus mean pre $45.4 \mathrm{~m}, 95 \%$ CI $(37.1,53.8)$; frequency: mean $_{\text {post }} 2.4$ dives $\mathrm{h}^{-1}, 95 \%$ CI $(1.8,2.9)$ versus mean ${ }_{\text {pre }} 5.4$ dives $\mathrm{h}^{-1}, 95 \%$ CI $(5.0,5.8)$; duration: mean $_{\text {post }} 13.1 \mathrm{~min}, 95 \%$ CI $(11.2,15.1)$ versus mean pre $_{6.1} \mathrm{~min}, 95 \%$ CI $(5.5,6.6)$. A pre-nesting female was defined as one that attempted to nest but returned to the sea without laying eggs. This ADR deployment method provides a simpler and less intrusive alternative to other tag attachment methods, such as harness and tethers, when the research questions require only short deployment time of archival recorders.
\end{abstract}

KEY WORDS: Dermochelys coriacea $\cdot$ Diving behavior $\cdot$ Archival tag $\cdot$ Flipper tag $\cdot$ Time-depth recorder $\cdot A D R$

\section{INTRODUCTION}

Despite the growing interest in research and conservation of marine vertebrates, many aspects of their biology remain poorly understood. This is largely because many of them spend most of their time in remote coastal and offshore waters where they are relatively inaccessible. In recent years, however, the development of small electronic data recorders has enabled researchers to study the at-sea behavior of marine vertebrates that is often difficult to evaluate with conventional tracking techniques, such as radio and ultrasonic telemetry.
In general, 2 classes of data recorders are available for studying the at-sea behavior of large marine organisms: platform transmitter terminals (PTTs) and archival data recorders (ADRs). Both devices can be configured to collect information on light levels, sea water temperature, and dive depth, although each collects data in different ways. Because PTT transmitters transmit information to the ARGOS satellite system, only small amounts of data can be transmitted at once due to bandwidth limitations. Recorded data, therefore, are stored in a summarized format (e.g. dive data are stored in bins) and transmitted to provide summary histograms. Consequently, continuous dive 
records have typically been unavailable from PTTs, and only very recently have PTT systems been developed to provide information on dive profiles. Although the resolution of these data has been increasing, there remains a problem of transmitting high-frequency sampling data via satellite.

In contrast, ADRs can collect data on various physical variables, such as depth, temperature, light level, and time at much higher frequency than PTTs. Because data are stored on board, however, the recorder needs to be retrieved to recover the data. This presents challenges, both with regard to reliable attachment methods and the re-capture of the original individuals. For marine mammals, the recapture of tagged animals has been the critical problem for retrieving ADRs. Researchers have used corrosive links, remote release mechanisms, and suction cups to detach and retrieve ADRs from target animals (Acevedo-Gutierrez et al. 2002, Baird et al. 2005, Eguchi \& Harvey 2005). For marine turtles, however, recapture of nesting adult females at a nesting beach is a relatively easy task because they return to the nesting beach several times during a nesting season.

A variety of attachment methods have been tested to secure data recorders to adult female marine turtles at nesting beaches. Fiberglass and epoxy resin has been used successfully to attach various instruments to the carapace and head of hard-shelled turtles (Balazs et al. 1996, Hays et al. 2000, Mitchell 2000, Godley et al. 2002, Seminoff et al. 2002). For leatherback turtles Dermochelys coriacea, however, adhesive and resins are not effective for attaching data recorders due to their leathery carapace. Harnesses and tethers have been used to secure data recorders to leatherback turtles (Eckert \& Eckert 1986, Eckert et al. 1989, Morreale et al. 1996, Eckert \& Sarti 1997). Southwood et al. $(1999,2005)$ attached instruments to female leatherback turtles with stainless steel wires, which were secured directly to the turtle by drilling holes on the carapace. More recently, Reina et al. (2005) used suction cups to attach the housing for an integrated video/ADR on leatherback turtles.

Because of the technological advances in electronic data storage, the size of ADRs has been reduced dramatically in the recent years. Consequently, more options are available for attaching ADRs to large turtles. For leatherback turtles, small ADRs can be attached to the flipper tags that are routinely used in beach monitoring programs (Hays et al. 2004a). The approach is attractive because the animal handling time is minimized, no special tools and equipment are required, and no special training of personnel is necessary. Resulting dive data can provide insights into inter-nesting behavior of leatherbacks and other marine turtle species (Hays et al. 2004a).
In this study, we explored the utility of this technique by attaching ADRs to flipper tags of a nesting population of leatherback turtles. We investigated internesting diving behavior of females; specifically, we examined possible differences in diving behavior between pre-and post-nesting females. We defined pre-nesting females as those which attempted to nest but returned to the sea without laying eggs. These females returned to the nesting beach, often during the following evening, to complete their oviposition; females that nested successfully, i.e. post-nesting females, were not seen for another 9-12 d, when they returned to lay the next clutch of eggs (Eckert 1987, Boulon et al. 1996, Dutton et al. 2005).

\section{MATERIALS AND METHODS}

We deployed 10 ADRs on nesting female leatherback turtles between 2 and 12 June 2004 at Sandy Point Wildlife Refuge, St. Croix, US Virgin Islands. This is the site of a long-term program initiated in 1981 to monitor and protect nesting leatherback turtles and their eggs (Boulon et al. 1996). This conservation effort has resulted in an exponential increase in nesting females and hatchling production, and involved extensive research into a variety of aspects of leatherback biology (Eckert et al. 1989, McDonald \& Dutton 1996, Eckert 2002, Dutton et al. 2005). A detailed description of the study area and the beach monitoring program is available in Dutton et al. (2005).

A database for nesting females at Sandy Point was created during 2003. The database contained information on inter-nesting behavior of each previously tagged female and was accessible in the field via a pocket PC (3Com Palm V, Palm). The database enabled us to predict the approximate arrival date of previously tagged females at the beach. All the females we encountered were examined for existing flipper tags and passive-integrated transponder (PIT) tags, and information was cross-referenced via identification numbers in the database. Untagged females were tagged with inconel flipper tags (Style 681, National Band and Tag Company) to the trailing edge of a hind flipper and PIT tags (AVID2104, 14mm Euro PIT tag, Avid Microchip ID Systems) to the shoulder muscle. For all females, curved carapace length (CCL) and curved carapace width (CCW) were measured with a tape measure.

ADRs (LTD-1100, Lotek) were programmed to record time, depth, and ambient temperature every 10 s (64 Kbytes total memory). Each ADR measured $27 \times 20 \times 5 \mathrm{~mm}$ (length $\times$ width $\times$ height), and was secured to a plastic cattle ear tag (Y-TEX standard ear tag, Modern Farm) with quick-setting epoxy resin and 
a nylon-coated metal wire fitted through 2 holes in the ADR and flipper tag (Fig. 1). Each tag consisted of interlocking male and female parts. Standard cattle tag applicators were used to attach an ADR to one of the hind flippers of each turtle (Fig. 1). The tag was attached to the turtle when it was about to return to sea after unsuccessful nesting attempts or, in cases of successful nesters, after oviposition while the turtle was covering the nest with sand. One member of a 2-person team restrained the hind flipper while the other applied the tag. Care was taken not to interrupt the nesting process. For turtles that had abandoned their nesting attempts, care was also taken to wait until this was clearly evident; usually these events were the result of repeated collapses of nest cavities in conditions of dry sand.

When a female with an ADR returned to the beach, the ADR was recovered by cutting through the male part of the tag with a razor blade. Data were then

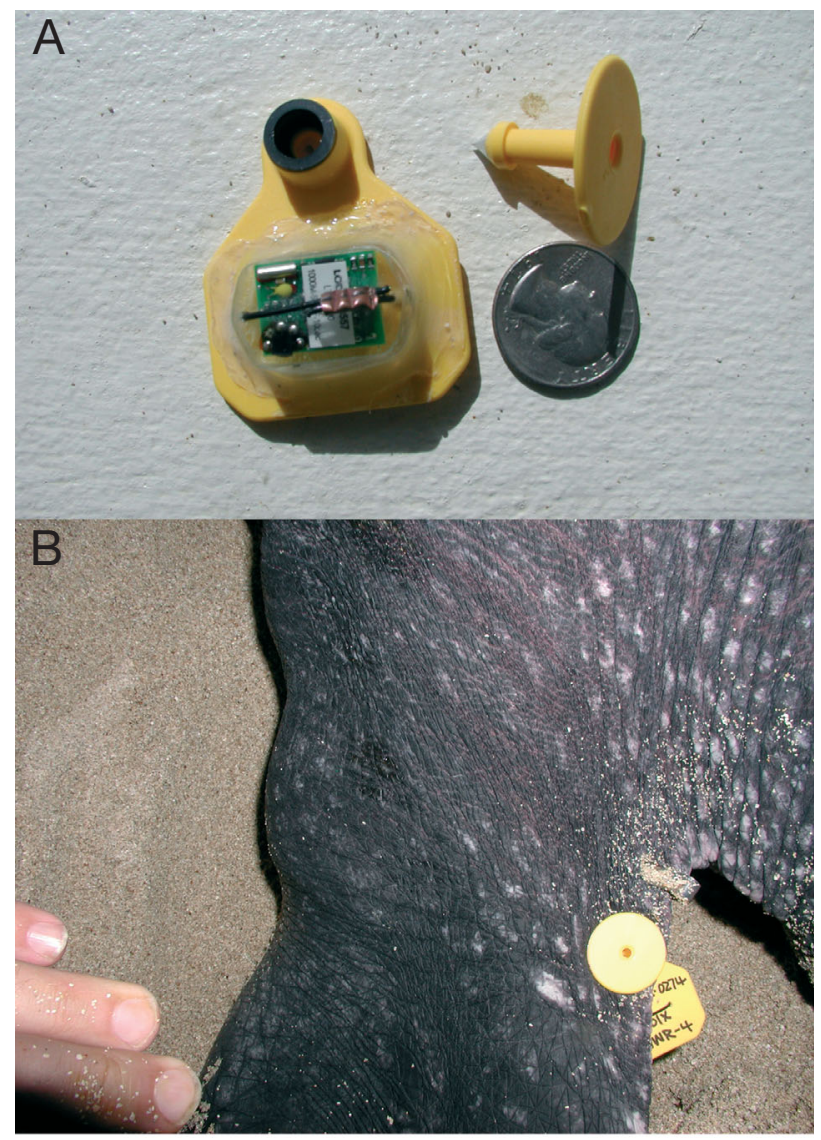

Fig. 1. (A) An ADR secured on a plastic cattle ear tag. The diameter of the coin is $2.4 \mathrm{~cm}$. To attach the tag to a flipper, tag applicators were used to protrude the male (circular) part through the female part from the bottom of the tag. To retrieve the tag, the stem of the male part was severed with a razor blade. (B) A deployed tag on the posterior edge of the left hind flipper of a female leatherback turtle; the bottoms of the male and female parts are shown downloaded to a personal computer via an infrared communication port and the manufacturer's software. To account for brief submergences of a data recorder, all dives with a maximum depth reading of $5 \mathrm{~m}$ were excluded from analyses. Statistical analyses and visualization of data were accomplished by using programming languages Matlab (The MathWorks) and R (www.r-project.org).

\section{RESULTS}

We deployed ADRs on 6 post-nesting females and 5 pre-nesting females. The average CCL of pre- and post-nesting females was $154.4 \mathrm{~cm}(\mathrm{SE} 3.6, \mathrm{n}=5)$ and $151.8 \mathrm{~cm}$ (SE 2.5, n =6), respectively (Table 1). Of the 10 tagged turtles, 8 did not appear to react to the tag application, while 2 reacted by rushing to the water immediately afterwards.

A total of 7 ADRs were retrieved at the beach (Table 1). Of these, 2 were recovered when females returned to nest again after successful nesting (XXZ160 and AAG270). Four ADRs were retrieved from females when they returned to nest at the beach subsequent to aborted nesting attempts (VI1062, AAR530, AAR548, and AAQ962). One female (AAV913) was tagged after her aborted nesting attempt. Although this turtle apparently nested the following night (Fig. 2), her ADR was not recovered then due to a lightning storm that prevented researchers from going to the beach. Data for this female, therefore, were separated into apparent pre-nesting and post-nesting phases. The remaining 3 tagged turtles did not return to the study area for the rest of the field season. We hope to evaluate the long-term effects of tagging and the duration of deployments when these turtles return to the beach in the future.

For those turtles that returned to the beach during the field season, we found no evidence of tissue necrosis at the attachment site. In all cases, ADRs stayed on the flippers until they were removed by project staff.

Data were recorded for ca. 22 to $90 \mathrm{~h}$, where the mean for pre-nesting females was $31.5 \mathrm{~h}$ (SE 5.1) and the mean for post-nesting females was $81.6 \mathrm{~h}$ (SE 8.1). The average dive depth was greater for the post-nesting females - (mean $78.6 \mathrm{~m}, 95 \%$ CI $(56.0,101.2)-$ than for the pre-nesting females - (mean $45.4 \mathrm{~m}, 95 \%$ CI $(37.1,53.8)$ (Table 1). The average dive duration also was greater for post-nesting females (mean 13.1 $\min , 95 \%$ CI $(11.2,15.1)$ - than for pre-nesting females - (mean $6.1 \mathrm{~min}, 95 \%$ CI $(5.5,6.6)$ (Table 1). The number of dives per hour ranged from 4.9 to $6.1-$ (mean 5.43, 95\% CI $(5.03,5.83)$-for pre-nesting females, whereas for post-nesting females this ranged from 2.0 to 2.9 - (mean $2.37,95 \%$ CI $(1.85,2.90)$. 
Table 1. Body size (curved carapace length; CCL) and summary dive statistics for 10 nesting female leatherback turtles tagged with ADRs at Sandy Point, St. Croix, US Virgin Islands, during the 2004 nesting season. Data for AAV913 were split into pre-nesting and post-nesting phases (see text for details). Three tagged post-nesting females did not return to the beach

\begin{tabular}{|c|c|c|c|c|c|c|c|c|}
\hline ID & $\begin{array}{l}\text { Date } \\
\text { tagged }\end{array}$ & $\begin{array}{l}\mathrm{CCL} \\
(\mathrm{cm})\end{array}$ & $\begin{array}{c}\text { Time } \\
\text { recorded (h) }\end{array}$ & $\begin{array}{l}\text { No. } \\
\text { dives }\end{array}$ & $\begin{array}{c}\text { Mean (SD) } \\
\text { depth (m) }\end{array}$ & $\begin{array}{l}\text { Maximum } \\
\text { depth (m) }\end{array}$ & $\begin{array}{c}\text { Mean (SD) } \\
\text { duration (min) }\end{array}$ & $\begin{array}{c}\text { Maximum } \\
\text { duration (min) }\end{array}$ \\
\hline \multicolumn{9}{|c|}{ Pre-nesting females } \\
\hline VI1062 & $6 / 3 / 2004$ & 159.5 & 22.18 & 118 & $39.7(54.9)$ & 215.8 & $5.4(5.4)$ & 23.0 \\
\hline AAR530 & $6 / 3 / 2004$ & 160.6 & 25.49 & 156 & $32.3(33.8)$ & 175.6 & $5.8(4.2)$ & 18.0 \\
\hline AAR548 & $6 / 3 / 2004$ & 159.0 & 44.15 & 214 & $56.8(44.2)$ & 195.1 & $7.0(3.8)$ & 16.3 \\
\hline AAQ962 & $6 / 5 / 2004$ & 151.0 & 43.59 & 237 & $49.9(51.4)$ & 212.2 & $6.4(4.7)$ & 18.5 \\
\hline AAV913 & $6 / 8 / 2004$ & 141.9 & 22.08 & 120 & $48.5(57.6)$ & 248.5 & $5.8(4.3)$ & 18.3 \\
\hline $\begin{array}{l}\text { Average } \\
\text { (SE) }\end{array}$ & & $\begin{array}{c}154.4 \\
(3.6)\end{array}$ & $\begin{array}{l}31.5 \\
(5.1)\end{array}$ & $\begin{array}{c}169 \\
(24.3)\end{array}$ & $\begin{array}{l}45.4 \\
(4.3)\end{array}$ & $\begin{array}{l}209.4 \\
(12.1)\end{array}$ & $\begin{array}{c}6.1 \\
(0.28)\end{array}$ & $\begin{array}{l}18.8 \\
(1.1)\end{array}$ \\
\hline \multicolumn{9}{|c|}{ Post-nesting females } \\
\hline XXZ160 & $6 / 3 / 2004$ & 149.5 & 90.46 & 184 & $101.4(54.1)$ & 289.2 & $14.9(5.4)$ & 23.3 \\
\hline AAG270 & $6 / 3 / 2004$ & 157.3 & 88.93 & 194 & $64.5(57.9)$ & 479.7 & $13.1(6.8)$ & 27.8 \\
\hline XXZ034 & $6 / 3 / 2004$ & 151.4 & - & - & - & - & - & - \\
\hline AAR548 & $6 / 5 / 2004$ & 159.0 & - & - & - & - & - & - \\
\hline KL52 & $6 / 6 / 2004$ & 151.6 & - & - & - & - & - & - \\
\hline AAV913 & $6 / 8 / 2004$ & 141.9 & 65.34 & 190 & $69.9(62.2)$ & 360.0 & $11.4(5.9)$ & 22.0 \\
\hline $\begin{array}{l}\text { Average } \\
\text { (SE) }\end{array}$ & & $\begin{array}{l}151.8 \\
(2.5)\end{array}$ & $\begin{array}{l}81.6 \\
(8.1)\end{array}$ & $\begin{array}{l}189.3 \\
(2.9)\end{array}$ & $\begin{array}{c}78.6 \\
(11.5)\end{array}$ & $\begin{array}{l}376.3 \\
(55.6)\end{array}$ & $\begin{array}{l}13.1 \\
(1.0)\end{array}$ & $\begin{array}{l}24.4 \\
(1.8)\end{array}$ \\
\hline
\end{tabular}

\section{DISCUSSION}

Numerous studies have been conducted to monitor underwater behavior and movements of diving animals via archival and satellite telemetry devices. These studies have provided valuable information

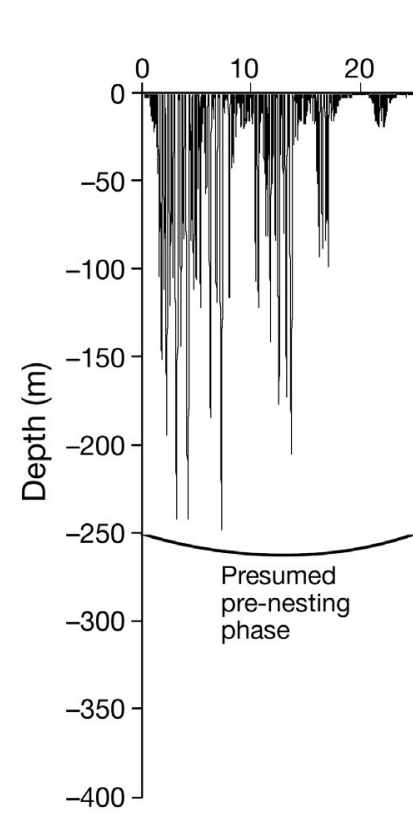

Time since first reading (h)

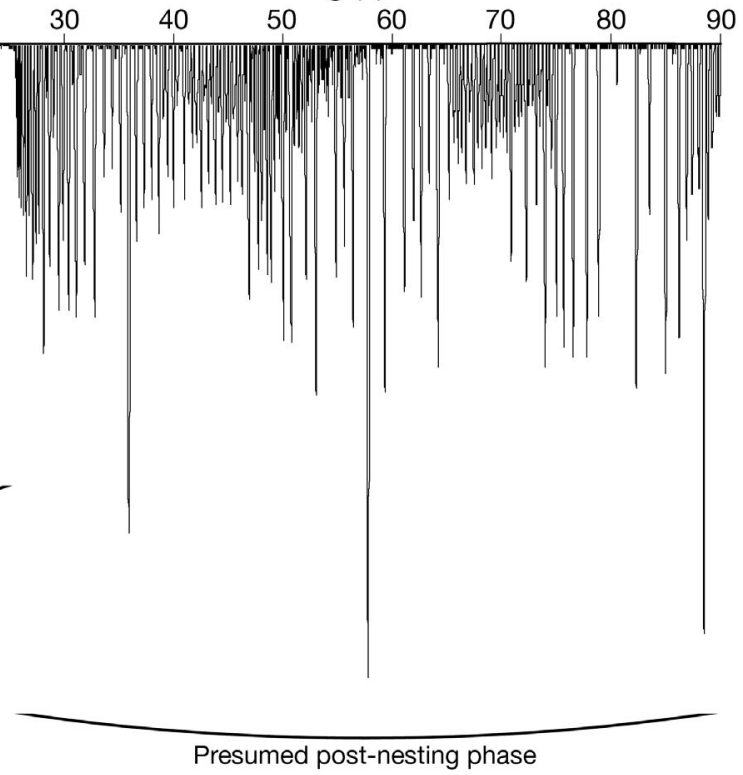

Fig. 2. Dive records of a female leatherback turtle (AAV913) tagged with an ADR at Sandy Point National Wildlife Refuge, St. Croix, US Virgin Islands. Data were separated into 2 apparent phases: pre- and post-nesting. Dive data for other females were similar about otherwise unobservable diving behavior. In studies of diving animals using electronic devices, data from instrumented animals are considered as a random sample from the entire population or species. Consequently, it is important to evaluate the extentto which handling, instruments, and attachment methods affect the instrumented animals.

Researchers have investigated effects of instruments on the status, such as survival, reproduction, and behavior, of their research animals. For diving birds, researchers have suggested that tag mass or cross-sectional area may affect foraging efficiencies (Wilson et al. 1986, Hull 1997). Gauthier-Clerc et al. (2004) reported that banding negatively affected the reproductive potential of the King Penguin Aptenodytes patagonicus, including late arrival at the colony for courtship in some years, lower breeding probability, and lower chick production. Hamel et al. (2004), however, found no effects of subcutaneous transmitters on overall reproductive success in the Common Murre Uria aalge on Tatoosh Island, Washington.

Although we did not explicitly address the possible effects of the tagging method on nesting female leatherback turtles, we think that the ADR and plastic tags used in this study 
had small to negligible effects on diving behavior for the following reasons: (1) the majority of instrumented turtles looked and behaved normally after they were tagged on the beach; (2) instrumented turtles returned to nest at Sandy Point Wildlife Refuge, indicating that the transmitters and the tagging experience did not deter turtles from re-nesting; (3) the application of the tag to the hind flipper required negligible mutilation of the flipper; (4) these cattle tags are designed to be applied to cattle ears in a similar fashion; and (5) the weight of a transmitter package was $<0.1 \%$ of body mass. Mellas \& Haynes (1985) have shown that a transmitter will not cause negative effects on fish if its weight is less than $2 \%$ of the instrumented individual's body mass. Further, by attaching an ADR to a hind flipper, rather than to the carapace, the increase in hydrodynamic drag caused by the tag was probably minimal. Watson \& Granger (1998) reported that carapace-mounted satellite transmitters can increase the hydrodynamic drag, thereby potentially reducing the swimming speed of green turtles by $11 \%$. Finally, considering the extent of natural scars observed on leatherback turtles, application of these tags to flippers likely had no lasting, if any, negative effects. These cattle tags have been used successfully on various species of pinnipeds and sea otters for individual identification purposes (Gilmartin et al. 1993, Hatfield \& Rathbun 1996). Although 2 females rushed to the water after tags were applied, we think that long-term deleterious effects of tagging on their natural behavior were negligible.

Although the application and retrieval of tags was successful, there are several potential improvements and considerations. (1) The amount of on-board memory should be determined based on the questions to be answered in a study. There is a trade-off between the amount of on-board memory and the physical size of a recorder. For example, if the goal of a study is to obtain dive data over the entire nesting season, the memory size should be maximized. The size of the recorder, however, would increase with the memory size. On the other hand, if the research question requires dive records of several days, the memory size may be minimized so that the recorder can be smaller. Physical size of the recorder should be minimized to reduce drag. (2) The method by which data are downloaded may be improved. Because data can be downloaded from these tags via an infrared port, it may be possible to download data to a field computer without removing the tag from the turtle at the nesting beach while the animal attempts to nest. (3) The ADR and its attachment methods should be modified or a better tool should be developed to enable easier tag excision. Both (2) and (3) would minimize potential injuries to turtles and researchers. Hays et al. (2004b) reported successful deployments of similar recorders by attaching an ADR directly to a flipper tag with a wire, which can be cut to retrieve the ADR without removing the flipper tag. More research is necessary to reduce handling time and mutilation of animals when electronic recorders and transmitters are deployed to study their natural behavior.

The main purpose of this study was to evaluate the use of plastic cattle ear tags as platforms for the shortterm deployment of ADRs. In the process, however, we collected dive data and found a difference in diving behavior between post-nesting and pre-nesting females. Although the sample size was small, we found shorter, shallower, and more frequent dives for prenesting females than for post-nesting females (Table 1). Longer duration of dives for post-nesting females was probably the result of deeper dives by these females. Positive correlations between dive depth and duration have been reported for a variety of diving animals, including leatherback turtles (Martin \& Smith 1999, Costa \& Gales 2000, Reina et al. 2005).

There are several possible reasons for the observed difference in diving behavior between the 2 groups of female leatherback turtles. Because nesting at a tropical beach may be a source of thermal stress for females (Miller 1997), post-nesting individuals may spend more time at depth, where ambient water temperature is cooler. A similar result has been reported for leatherback turtles in Costa Rica (Southwood et al. 2005). Alternatively, the energetic stress of nesting behavior may explain the observed difference. Postnesting females may reduce their energy expenditure by reducing the amount of active swimming in the water column. Researchers have shown that marine mammals use drift diving during the descent phase of deep dives, thereby minimizing energy expenditure (Crocker et al. 1997, Webb et al. 1998, Skrovan et al. 1999, Page et al. 2005). Leatherback turtles may use the similar approach to conserve their energy after oviposition. Conversely, pre-nesting females may not be able to dive as far down as post-nesting females because of physiological constraints from the eggs in their ovaries.

Physiological studies are necessary to elucidate reasons for the observed difference in diving behavior between post- and pre-nesting females. Such studies may require recording internal and body-surface temperature (Boyd 2000, Southwood et al. 2005), using ${ }^{18} \mathrm{O}$ doubly-labeled water (Costa \& Gales 2000), and measuring locomotion of individuals (Williams et al. 2004, Reina et al. 2005).

Previous studies have indicated a change in diving behavior of female marine turtles during inter-nesting periods. Hays et al. (1991) tracked a loggerhead turtle 
Caretta caretta via satellite telemetry and found that the turtle stayed near shore during the inter-nesting period. Hays et al. (1999) reported a decline in the average duration of submergence as a function of time since nesting in green turtles Chelonia mydas at Ascension Island. They suggested that green turtles rested on the sea floor immediately after nesting, thus increasing the average duration of submergence then. Houghton et al. (2002) used ADRs to study inter-nesting diving behavior of loggerhead turtles in Cyprus. They reported dichotomous diving behavior from 2 tagged females; one rested on the sea floor, whereas the other spent more time foraging. These studies indicated large variability in diving behavior among nesting females during the inter-nesting period.

Our findings of diving behavior during the internesting period were similar to results of previous studies at the same location. Eckert et al. (1989) and Eckert (2002) attached time-depth recorders to post-nesting female leatherback turtles at Sandy Point National Wildlife Refuge. They reported the average dive depths to be $64.5 \mathrm{~m}$ (SE 12.0, $\mathrm{n}=6$; Eckert et al. 1989) and $78.5 \mathrm{~m}$ (SE 14.5, $\mathrm{n}=2$; Eckert 2002), whereas the average durations were $10.3 \mathrm{~min}$ (SE 1.1, $\mathrm{n}=6$; Eckert et al. 1989) and $10.3 \mathrm{~min}$ (SE 0.05, $\mathrm{n}=2$; Eckert 2002). Extremely deep (>1000 m) and long dives reported in Eckert et al. (1989) were not found in our study. Although it has been reported that leatherback turtles can dive deeper than $1000 \mathrm{~m}$ and longer than $30 \mathrm{~min}$, these dives are rare (Hays et al. 2004b). The sample sizes of these studies were too small to make conclusive remarks on diving behavior of nesting leatherback turtles. We plan to collect more data on diving behavior of post- and pre-nesting leatherback turtles at Sandy Point National Wildlife Refuge in the near future using the least intrusive methods possible.

\section{CONCLUSIONS}

We have shown that plastic cattle ear tags may be used to deploy ADRs on leatherback turtles and possibly on other marine turtles and other diving animals. Although minor modifications may be necessary to streamline the process of tagging and retrieving ADRs, the tagging method is a viable alternative to more elaborate harness systems or tether attachments, especially when a research question requires short duration of ADR deployment. Further improvements on existing technologies, tagging methods, and retrieval of ADRs increase the potential for researchers to address a wide range of questions on endangered marine turtle species. More studies are necessary to evaluate potential negative effects of instruments and handling on diving animals.
Acknowledgements. We thank Jeremy Conrad, Kendra Garrett, Lauren Hansen, Erin LaCasella, Robin LeRoux, Suzanne Roden, and numerous Earthwatch volunteers for their help in the field. We also thank Manjula Tiwari, G. C. Hays and 2 anonymous reviewers for comments that improved earlier versions of this manuscript. This study was conducted under special use permit \#2004-002 (USFWS). Funding was provided in part by Earthwatch Research Institute and NMFS Southwest Fisheries Science Center.

\section{LITERATURE CITED}

Acevedo-Gutiérrez A, Croll DA, Tershy BR (2002) High feeding costs limit dive time in the largest whales. J Exp Biol 205:1747-1753

Baird RW, Hanson MB, Dill LM (2005) Factors influencing the diving behaviour of fish-eating killer whales: sex differences and diel and interannual variation in diving rates. Can J Zool 83:257-267

Balazs GH, Russell KM, Beaver SC (1996) Procedures to attach a satellite transmitter to the carapace of an adult green turtle, Chelonia mydas. In: Keinath JA, Barnard DE, Musick JA, Bell BA (compilers) Proc Fifteenth Annu Symp Sea Turtle Biol Conserv. NOAA Technical Memorandum NMFS-SEFSC-387, Miami, FL, p 21-26. Available at: http://www.nmfs.noaa.gov/pr/readingrm/turtlesymp/ 15turtle.pdf

Boulon RH, Dutton PH, McDonald DL (1996) Leatherback turtles (Dermochelys coriacea) on St. Croix, US Virgin Islands: fifteen years of conservation. Chel Cons Biol 2: 141-147

Boyd L (2000) Skin temperatures during free-ranging swimming and diving in Antarctic fur seals. J Exp Biol 203: $1907-1914$

Costa DP, Gales NJ (2000) Foraging energetics and diving behavior of lactating New Zealand sea lions, Phocarctos hookeri. J Exp Biol 203:3655-3665

Crocker D, Le Boeuf BJ, Costa DP (1997) Drift diving in female northern elephant seals: implications for food processing. Can J Zool 75:27-39

Dutton DL, Dutton PH, Chaloupka M, Boulon RH (2005) Increase of a Caribbean leatherback turtle Dermochelys coriacea nesting population linked to long-term nest protection. Biol Cons 126:186-194

Eckert KL (1987) Environmental unpredictability and leatherback sea turtle (Dermochelys coriacea) nest loss. Herpetologica 43:315-323

Eckert SA (2002) Swim speed and movement patterns of gravid leatherback sea turtles (Dermochelys coriacea) at St Croix, US Virgin Islands. J Exp Biol 205:3689-3697

Eckert SA, Eckert KL (1986) Harnessing leatherbacks. Mar Turt Newsl 37:1-3

Eckert SA, Sarti L (1997) Distant fisheries implicated in the loss of the world's largest leatherback nesting population. Mar Turt Newsl 78:2-7

Eckert SA, Eckert KL, Ponganis P, Kooyman GL (1989) Diving and foraging behavior of leatherback sea turtles (Dermochelys coriacea). Can J Zool 67:2834-2840

Eguchi T, Harvey JT (2005) Diving behavior of the Pacific harbor seal (Phoca vitulina richardii) in Monterey Bay, California. Mar Mamm Sci 21:283-295

Gauthier-Clerc M, Gendner JP, Ribic CA, Fraser WR and 5 others (2004) Long-term effects of flipper bands on penguins. Proc R Soc Lond B (Suppl) 271:S423-S426

Gilmartin WG, Johanos TC, Eberhardt LL (1993) Survival rates for the Hawaiian monk seal (Monachus schauins- 
landi). Mar Mam Sci 9:407-420

Godley BJ, Richardson S, Broderick AC, Coyne MS, Glen F, Hays GC (2002) Long-term satellite telemetry of the movements and habitat utilization by green turtles in the Mediterranean. Ecography 25:352-362

Hamel NJU, Parrish, JK, Conquest LL (2004) Effects of tagging on behavior, provisioning, and reproduction in the common murre (Uria aalge), a diving seabird. Auk 121: 1161-1171

Hatfield BB, Rathbun GB (1996) Evaluation of a flippermounted transmitter on sea otters. Wildl Soc Bull 24: 551-554

Hays GC, Webb PI, Hayes JP, Priede IG, French J (1991) Satellite tracking of a loggerhead turtle (Caretta caretta) in the Mediterranean. J Mar Biol Assoc UK 71:743-746

Hays GC, Luschi P, Papi F, del Seppia C, Marsh R (1999) Changes in behaviour during the inter-nesting period and post-nesting migration for Ascension Island green turtles. Mar Ecol Prog Ser 189:263-273

Hays GC, Adams CR, Broderick AC, Godley BJ, Lucas DJ, Metcalfe JD, Prior AA (2000) The diving behaviour of green turtles at Ascension Island. Anim Behav 59:577-586

Hays GC, Houghton JDR, Isaacs C, King RS, Lloyd C, Lovell P (2004a) First records of oceanic dive profiles for leatherback turtles, Dermochelys coriacea, indicate behavioural plasticity associated with long-distance migration. Anim Behav 67:733-743

Hays GC, Houghton JDR, Myers AE (2004b) Pan-Atlantic leatherback turtle movements. Nature 429:522

Houghton JDR, Broderick AC, Godley BJ, Metcalfe JD, Hays GC (2002) Diving behaviour during the internesting interval for loggerhead turtles (Caretta caretta) nesting in Cyprus. Mar Ecol Prog Ser 227:63-70

Hull CL (1997) The effect of carrying devices on breeding royal penguins. Condor 99:530-534

Martin AR, Smith TG (1999) Strategy and capability of wild belugas, Delphinapterus leucas, during deep, benthic diving. Can J Zool 77:1783-1793

McDonald DL, Dutton PH (1996) Use of PIT tags and photo identification to revise remigration estimates of leatherback turtles (Dermochelys coriacea) nesting in St. Croix, US Virgin Islands, 1979-1995. Chel Cons Biol 2: 148-152

Mellas EJ, Haynes JM (1985) Swimming performance and behavior of rainbow trout (Salmo gairdneri) and white perch (Morone americana): effects of attaching telemetry transmitters. Can J Fish Aquat Sci 42:488-493

Editorial responsibility: Brendan Godley, Penryn, UK
Miller JD (1997) Reproduction in sea turtles. In: Lutz PL, Musick JA, (eds) The biology of sea turtles. CRC Press LLC, Boca Raton, FL, p 51-81

Mitchell S (2000) Use of epoxy in telemeter attachment. In: Abreu-Grobois FA, Briseño-Dueñas R, MárquezMillán R, Sarti-Martínez AL (compilers) Proc 18th Sea Turtle Symp. NOAA Tech Memo NMFS-SEFSC-436, Miami, FL, p 254-255. Available at: http:// www.nmfs.noaa.gov/pr/readingrm/turtlesymp/18turtle.pdf

Morreale SJ, Standora EA, Spotila JR, Paladino FV (1996) Migratory corridor for sea turtles. Nature 384:319-320

Page B, McKenzie JM, Hindell A, Goldsworthy SD (2005) Drift dives by male New Zealand fur seals (Arctocephalus forsteri). Can J Zool 83:293-300

Reina RD, Abernathy KJ, Marshall GJ, Spotila JR (2005) Respiratory frequency, dive behaviour and social interactions of leatherback turtles Dermochelys coriacea during the inter-nesting interval. J Exp Mar Biol 316:1-16

Seminoff JA, Resendiz A, Nichols WJ (2002) Home range of the green turtle Chelonia mydas at a coastal foraging ground in the Gulf of California, México. Mar Ecol Prog Ser 242:253-265

Skrovan RC, Williams TM, Berry PS, Moore PW, Davis RW (1999) The diving physiology of bottlenose dolphins (Tursiops truncatus) II. Biomechanics and changes in buoyancy at depth. J Exp Biol 202:2749-2761

Southwood AL, Andrews RD, Lutcavage ME, Paladino FV, West NH, George RH, Jones DR (1999) Heart rates and diving behavior of leatherback sea turtles in the Eastern Pacific Ocean. J Exp Biol 202:1115-1125

Southwood AL, Andrews RD, Paladino FV, Jones DR (2005) Effects of diving and swimming behavior on body temperatures of Pacific leatherback turtles in tropical seas. Phys Biochem Zool 78:285-297

Watson KP, Granger RA (1998) Hydrodynamic effect of a satellite transmitter on a juvenile green turtle (Chelonia mydas). J Exp Biol 201:2497-2505

Webb PM, Crocker DE, Blackwell SB, Costa DP, Le Boeuf BJ (1998) Effects of buoyancy on the diving behavior of northern elephant seals. J Exp Biol 201:2349-2358

Williams TM, Fuiman LA, Horning M, Davis RW (2004) The cost of foraging by a marine predator, the Weddell seal Leptonychotes weddellii: pricing by the stroke. J Exp Biol 207:973-982

Wilson RP, Grant WS, Duffy DC (1986) Recording devices on free-ranging marine animals: does measurement affect foraging performance? Ecology 67:1091-1093

Submitted: January 24, 2006; Accepted: March 20, 2006

Proofs received from author(s): April 25, 2006 